\title{
Monthly Chaetocerotales diversity and abundance, and its relationship with water physicochemical parameters and phytoplankton diversity in Carey Island mangrove ecosystem, Malaysia
}

\author{
NURUL SHAHIDA REDZUAN ${ }^{1,2}$, POZI MILOW ${ }^{2}$ \\ ${ }^{1}$ Faculty of Science and Marine Environment, Universiti Malaysia Terengganu. 21030 Kuala Nerus, Terengganu, Malaysia \\ Tel./fax.+60-194570311, "email: nurulshahida@umt.edu.my \\ ${ }^{2}$ Institute of Biological Sciences, Faculty of Science, Universiti Malaya. 50603 Kuala Lumpur, Malaysia
}

Manuscript received: 28 April 2021. Revision accepted: 26 June 2021

\begin{abstract}
Redzuan NS, Milow P. 2021. Monthly Chaetocerotales diversity and abundance, and its relationship with water physicochemical parameters and phytoplankton diversity in Carey Island mangrove ecosystem, Malaysia. Biodiversitas 22: $2919-2927$. Globally, phytoplankton of order Chaetocerotales has been reported to cause monospecific bloom events. The blooms that normally lead to ecosystem instability, also physically responsible for histological and physical damages to fishes. Regarding that order Chaetocerotales often display significant temporal variability, this study aimed to investigate the monthly variability of species composition and cell density of phytoplankton of order Chaetocerotales during high tide period immersion were investigated over a year period. In addition, this present study also aimed to analyze the relationship between Chaetocerotales diversity and abundance with physical and chemical parameters that potentially controlling their temporal variability. Samplings were carried out from April 2009 until March 2010 in the mangrove ecosystem of Carey Island, Selangor, Malaysia. Of 84 phytoplankton taxa recorded, 18 species belonged to order Chaetocerotales, i.e. the genera Bacteriastrum and Chaetoceros. Although initially the sampling was designed to study the overall phytoplankton, the study also aimed at high temporal variability in Chaetocerotaceae cells density has called for this paper to be written. Interestingly, order Chaetocerotales showed to have negative correlation with the total phytoplankton species. Chaetocerotales blooms at the study site were represented by multispecies blooms, with Chaetoceros curvisetus as the highest species in the events. Dissolved oxygen, on the other hand, showed to have negative correlation Chaetocerotales' cells density. All of the species, except the Chaetoceros subtilis and Chaetoceros neglectus displayed significant temporal monthly variability across twelve months of sampling. Nitrate, phosphate and temperature are potentially the parameters that stimulate the growth of the order, consequently causing bloom events.
\end{abstract}

Keywords: Chaetocerotales, Carey Island, mangrove ecosystem, Chaetoceros, Bacteriastrum

\section{INTRODUCTION}

Chaetocerotales is one of the common orders within the division of Bacillariophyta that inhabits both marine and mangrove ecosystems in the tropical region. Attention has been given to this phytoplankton order due to its progressively increasing importance in aquaculture, medicine and biotechnology. Chaetocerotales have been documented as vital source of antifreeze protein (Gwak et al. 2010) and source of food in aquaculture feeds (Hashimoto et al. 2008; Kang et al. 2009). Ecologically, Chaetocerotales are frequently reported as the phytoplankton group that responsible for annual early spring bloom by forming the Chaetoceros-dominated chain in various regions of the world (Ishikawa and Furuya 2004; Booth et al. 2002; Poulsen and Reuss 2002).

The member of the order Chaetocerotales can be distinguished from the other phytoplankton groups by means of their long spiny setae that protruding from their valves (Hasle and Syvertsen, 1997). This unique structure also reported being responsible to cause fish kills and harmful to various types of invertebrates all around the world ( Ochieng and Mary 2013; Bosch-Belmar et al. 2017;
Paterson et al. 2017). Bruno et al. (1989) reported that fish mortality is commonly attributed to this phytoplankton order. Their silicified frustules and setae are able to directly clog and penetrate into fishes' gills, causing severe histological damage.

Temporal distribution of Chaetocerotales often demonstrates high variability due to physicochemical factors (Brunet and Luzon 2003; Carter, et al. 2005; Facca and Sfriso 2007; Frankovich et al. 2010). In Mediterranean coasts, temperature, salinity and phosphate concentrations in the water column were proven to stimulate dominant Chaetocerotacean species succession (Bosak et al. 2016). The study also stated that warmer seasons such as in summer, frequently triggered monospecific bloom events. In Malaysia, Chaetocerotales primarily from the genus of Chaetoceros were commonly reported as dominant coastal phytoplankton species (Razali et al. 2015; Chang Lim et al. 2014; Sidik et al. 2008). Chaetocerotales species in the aquaculture area of Aman Island, Malaysia, positively correlate to physical parameters, $\mathrm{pH}$, salinity, and temperature (Razali et al. 2015). Although there is yet event of severe fish kills and bloom by order Chaetocerotales in Malaysia, increasing anthropogenic 
emissions, active aquaculture and climate change, possibly will increase the potential of bloom events to happen. Moore et al. (2008) hypothesized that global warming potentially initiates high water body temperature, more acidic aquatic and marine $\mathrm{pH}$ and also changes in evaporation patterns. Although the mentioned changes are most likely to lead to higher frequency of harmful algal bloom events, very little attention has been given to study the ecology of these harmful blooms.

To date, there is still no comprehensive study has ever been done exclusively on the Chaetocerotales ecology in Malaysia. Most attention has only been given to investigate the distribution and occurrence of total phytoplankton, not specifically on only one order or group. Therefore, in this study, phytoplankton was collected to investigate and update the species composition of Chaetocerotales variation over a year. Therefore, this study aimed to investigate the monthly variability of species composition and cell density of Chaetocerotales phytoplankton over a year in a mangrove ecosystem of Carey Island, Selangor, Malaysia. As part of monitoring program, this temporal distribution study also includes the relationship between Chaetocerotales with physicochemical parameters that potentially controlling their variability in the water column. Considering the anticipated environmental changes caused by anthropogenic and climatic factors in the future, we expected this study to provide an informative record on the dynamic of this phytoplankton group, which is also listed as the group that has high potential cause global harmful blooms. Mangrove ecosystem was chosen as the study site in this scientific investigation to better understand the ecology of estuarine Chaetocerotales. The ecosystem that is considered as an extreme habitat for the phytoplankton, should provide a new underpinning ecological information on this phytoplankton group, the Chaetocerotales.

\section{MATERIALS AND METHODS}

\section{Study site}

Mangrove ecosystem $\left(02^{\circ} 92^{\prime} \mathrm{N}, 101^{\circ} 35^{\prime} \mathrm{E}\right)$ of Carey Island, Malaysia was chosen as the study site (Figure 1). The ecosystem lies along Langat River estuarine Banting, Selangor state, Malaysia. Listed by the Malaysian Wetland Working Group as mangrove island, Carey Island is mostly surrounded by mangrove areas, thus, making the ecosystem a suitable area to study phytoplankton of the genus Chaetocerotales that inhabit the mangrove. Influx of water from Sungai Langat that flows into the mangrove ecosystem makes the water brackish and slightly acidic. Langat River flows along $120 \mathrm{~km}$ westward into Straits of Malacca and receives huge amounts of domestic and industrial wastes each year which normally will also affect the chemical and physical profiles of the research area.

Three stations were chosen to obtain the phytoplankton samples, namely ST1, ST2, and ST3 (Figure 1). The stations or sites were chosen based on their horizontal distance to the river mouth that displayed significant salinity gradient. ST1 was located upstream of the river and was adjacent to a shrimp aquaculture pond. ST2 positioned in a radius of $50 \mathrm{~m}$ to an oil palm process plant, while ST3 was the nearest site to the river mouth.
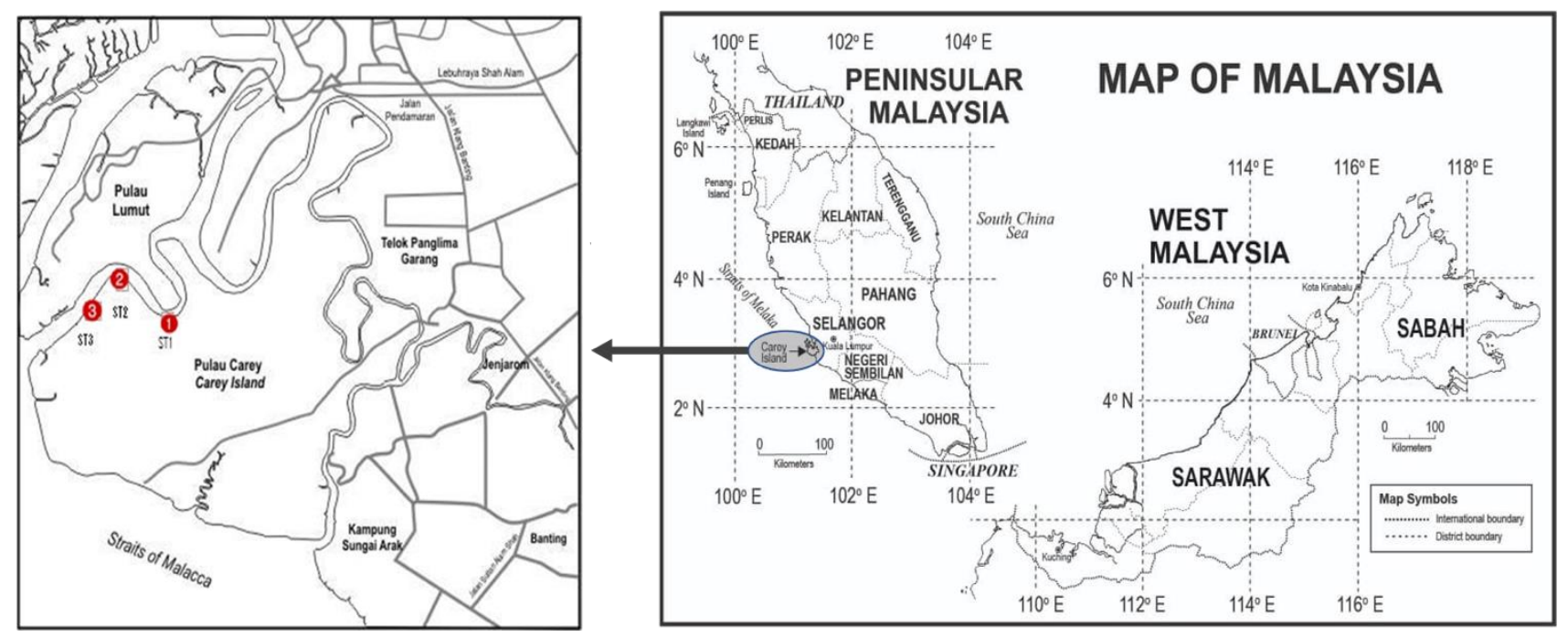

Figure 1. Map of Pulau Carey, Selangor, Malaysia and the study sites which consisted of three observation stations (i.e ST1, ST2 and ST3) 


\section{Phytoplankton sampling, enumeration and identification}

Monthly phytoplankton samplings were carried out from April 2009 until March 2010. The samplings were conducted once (for 1 day) in a month, with temporal gap between sampling occasions of 28-30 days. Triplicate samples were obtained using a $30 \mu \mathrm{m}$ wire mesh plankton net and were preserved in $4 \%$ formalin for identification and enumeration purposes. A flow meter was attached at the mouth of the plankton net to determine the volume of water that passed through it. One $\mathrm{ml}$ of preserved algae sample was pipetted into utermöhl sedimentation tube, in which one drop of Lugol's iodine was added. Slides were prepared following the Bellinger and Sigee (2010) procedure. Phytoplankton cells were enumerated by dividing the sedimentation tube into four divisions. The enumeration was carried out from one division to another (Evans 1972) and was expressed in cells $\mathrm{L}^{-1}$. The slides prepared were also used in identification process of both the phytoplankton. Phytoplankton identification was done based on their morphology, down to genus or species level. Taxonomic keys by Tajudin and Salleh (2006) and Hasle and Syvertsen (1997) were used and referred for identification process.

\section{Water sampling and its physicochemical measurement}

Water samples for chemical analyses that were collected using Ruttner sampler were transferred into polythene bottles $(500 \mathrm{ml})$ and preserved using four percent (\%) formalin. Measurement of physical factors such as water temperature, $\mathrm{pH}$, salinity, water conductivity (CND), dissolved oxygen (DO) and total dissolved solid (TDS) were recorded in situ using a handheld YSI Model 556 MPS. Whereas, chemical analyses such as phosphate $\left(\mathrm{PO}_{4}\right.$ $\left.{ }^{3}\right)$, nitrate $\left(\mathrm{NO}_{3}{ }^{-2}\right)$, silicate $\left(\mathrm{SiO}_{3}\right)$ and sulfate $\left(\mathrm{SO}_{4}{ }^{-2}\right)$ were carried out in the laboratory. The collected water samples for the water chemical analyses were filtered using Whatman-microfilter paper. All of the nutrients analyses were spectrophotometrically measured using Spectrophotometer DR4000 HACH at the respective wavelength for each of the chemicals. The chemical concentrations were expressed in $\mathrm{mg} \mathrm{L}^{-1}$.

\section{Statistical analyses}

Monthly total phytoplankton and Chaetocerotales species diversity were investigated using evenness $(E)$ and Shannon Diversity Index $\left(\mathrm{H}^{\prime}\right)$. The indices were calculated using the Multi-Variate Statistical Package (MVSP) 3.1 software (Kovach, 1999). All of the data obtained from the three stations were pooled because of their dependency $(n=9)$. One-way Analysis of Variance (ANOVA) was performed on the data of Chaetocerotales cells density and physicochemical parameters to determine the monthly variability for twelve months. The $F$ values that contributed to different temporal variations at $p<0.05$ were considered significant. Principal Component Analyses (PCA) was performed using FactoMineR in R Statistical Software. The analyses were done on the log-transformed $(n+1)$ data of Chaetocerotales' cells density and the measured physicochemical parameters. The individual scores of the
PCA were then analyzed for temporal monthly variability of Chaetocerotales species composition. Only the first and the second component of the PCA were retained and used in the results and discussion. Also, the ordination of each of Chaetocerotales species and Physico-chemical parameters in dimension 1 (Dim. 1) and dimension 2 (Dim. 2) of the PCA were used to investigate any possible correlation between each of the species with the measured parameters.

\section{RESULTS AND DISCUSSION}

\section{Temporal physicochemical variability}

Nitrate and phosphate concentrations in the water column at the study sites significantly varied across the months over the year at $\mathrm{F}_{11,35}=16.48, p<0.001$ and $\mathrm{F}_{11,35}=3.491, p<0.05$, respectively. While both silicate and sulfate concentrations showed non-significant monthly variation. DO with annual mean value of $3.34 \pm 0.21 \mathrm{mg} \mathrm{L}^{-}$ 1 was the only physical parameter that insignificantly varied over the year (Table 1), whereas all the other parameters were temporally varied at monthly scale at $p<$ 0.001 (Table 1). Details data on the monthly mean of the physicochemical parameters are presented in Table S1 in supplementary data.

\section{Temporal variability of Order Chaetocerotales}

A total of 84 species of phytoplankton ((Redzuan and Milow 2019) were recorded at study site across the twelve consecutive months of sampling. Out of the 84 species, 18 species were from order Chaetocerotales, which comprised of two genera, Bacteriastrum and Chetoceros (Figure 2). Both were two common genera recorded in Carey Island mangrove ecosystem. This finding is in agreement with a study done by Bhattacharjee et al. (2013) that reported the genus Chaetoceros as one of dominant species in Sundarbans mangrove, India. The genus Bacteriastrum was absent from the Sundarbans mangrove ecosystem, but was reported in the estuary ecosystem of the Sundarbans (Manna et al. 2010). Both genera of Chaetocerotales are commonly reported in Malaysia coastline (Chang Lim et al. 2014; Sidik et al. 2008).

Table 1. The results of physical and chemical parameters $(n=12)$ measured at the study site (Mean value $\pm \mathrm{SE}$ )

\begin{tabular}{ll}
\hline Physical and chemical parameters & \\
\hline $\begin{array}{l}\text { Chemical parameters } \\
\text { Nitrate }\left(\mathrm{NO}_{3}^{-2}\right)\end{array}$ & $0.50 \pm 0.06 \mathrm{mg} \mathrm{L}^{-1}$ \\
Silicate $\left(\mathrm{SiO}_{3}\right)$ & $2.53 \pm 0.25 \mathrm{mg} \mathrm{L}^{-1}$ \\
Phosphate $\left(\mathrm{PO}_{4}^{-3}\right)$ & $0.94 \pm 0.1 \mathrm{mg} \mathrm{L}^{-1}$ \\
Sulfate $\left(\mathrm{SO}_{4}^{-2}\right)$ & $55.44 \pm 3.45 \mathrm{mg} \mathrm{L}^{-1}$ \\
& \\
Physical parameter & $30.26 \pm 0.21$ \\
Water temperature $\left({ }^{\circ} \mathrm{C}\right)$ & $42230.72 \pm 533.96$ \\
Conductivity $(\mu \mathrm{s} / \mathrm{cm})$ & $3.34 \pm 0.27$ \\
Dissolved oxygen $\left(\mathrm{mg} \mathrm{L}^{-1}\right)$ & $26.04 \pm 027$ \\
Total dissolved solid $\left(\mathrm{mg} \mathrm{L}^{-1}\right)$ & $7.44 \pm 0.07$ \\
pH & $24.84 \pm 0.45$ \\
Salinity (ppt) & \\
\end{tabular}


Species from both genera contributed to $21.4 \%$ of the total phytoplankton species. Species composition of order Chaetocerotales occurred in seven months (April 2009, May 2009, June 2009, August 2009, January 2010, February 2010, and March 2010) out of the twelve sampling months. Although the species were absent in five out of the twelve sampling months, their occurrence showed to have significant impact on the diversity of the total phytoplankton. Increased in the cells abundance of Chaetocerotales showed to have negative effect on the total phytoplankton diversity (Table 2). This phenomenon could potentially remark the onset of bloom by order Chaetocerotales at the study site.

The highest cell density was recorded in April 2009 (Figure 2) (Table 2) with recorded total cells abundance of $360 \times 10^{3}$ cells $\mathrm{L}^{-1}$. The month was also reflected by comparably high H' and $E$ values of 3.194 and 0.94 (Table 2), respectively, with Bacteriastrum comosum as the highest contributor of the order's cells abundance $(131.3 \mathrm{x}$ $10^{3}$ cells/L) (Figure 2). However, this finding coincided with relatively low $\mathrm{H}^{\prime}$ and $E$ values of the total phytoplankton (Table 2). Both values were 1.607 and 0.316, respectively. Cells abundance of the Chaetoceros curvisetus was significantly higher than other Chaetocerotales species in the months which the species occurred (Figure 2). The species' highest cells abundance was in May 2009 (149 x 10 $0^{3} \pm 9207.49$ cells/L) and concurrent with the relatively low H' and $E$ values of both total phytoplankton (Table 2) and order Chaetocerotales (Table 2). Each of the order Chaetocerotales species showed a significant monthly variability (all significant at $p$ $<0.05)$ with exception of two Chaetoceros species, the $C$. neglectus and $C$. subtilis. High $\mathrm{H}^{\prime}$ and $E$ among the Chaetocerotales group at the study site indicated higher chance of multispecies bloom rather than monospecific bloom events happening. This high multispecies' cells abundance of Chaetocerotales at study site is likely to mimic the multispecies bloom of the genus Chaetoceros on the Mediterranean coast during autumn which frequently triggered by mixing events of the water column (Bosak et al. 2016)

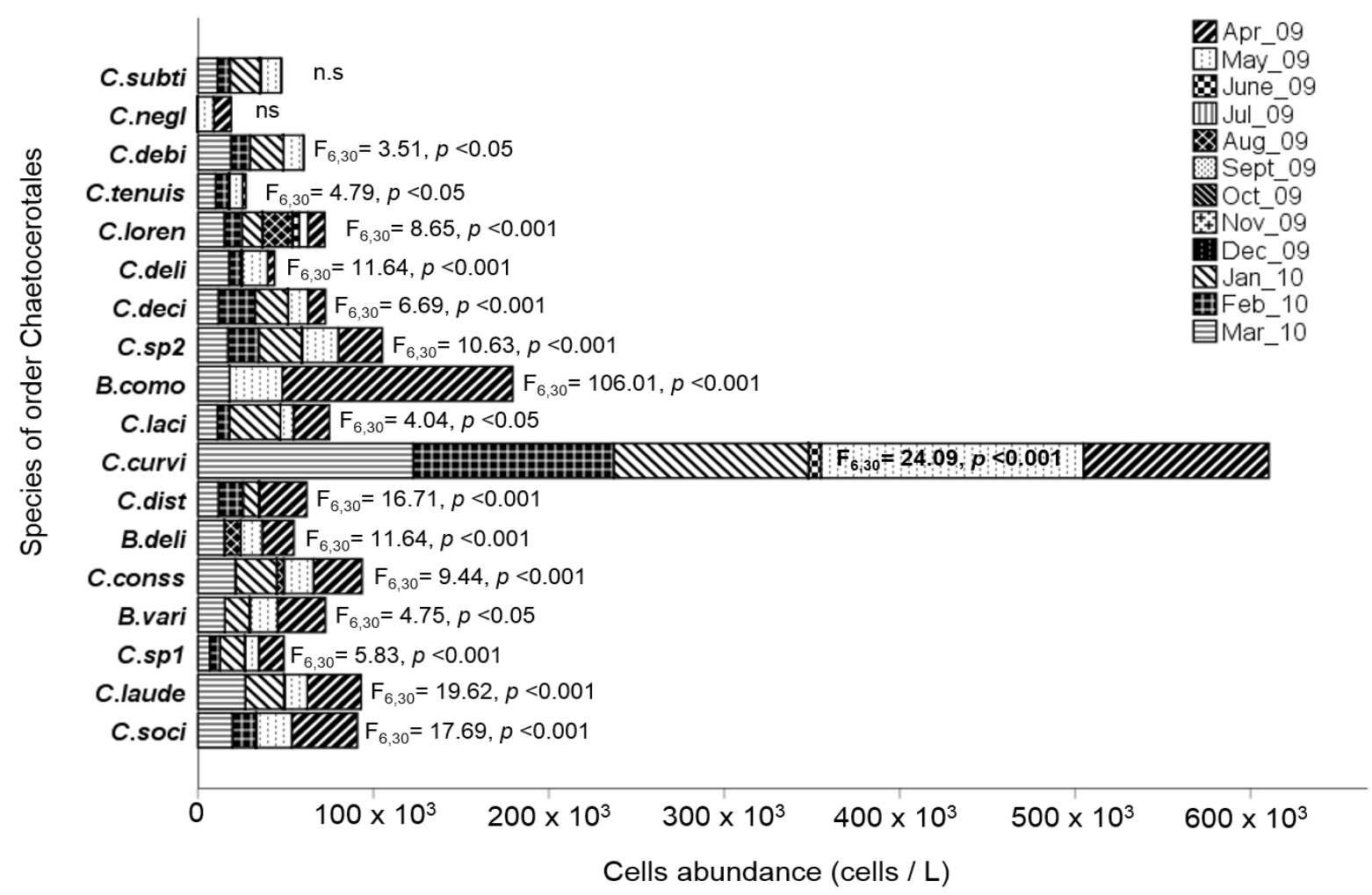

Figure 2. Cells density of order Chaetocerotales species composition across the twelve sampling months. Notes that standard error (SE) values are not presented in the figure. Also included the F-value and significant level for each of the species' monthly ANOVA output.

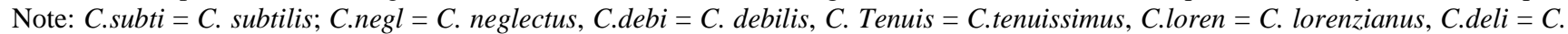
delicatulum, $C$. deci $=C$. decipiens, B.como $=B$. comosum, C.laci $=C$. laciniosum, C.curvi $=C$. curvisetus, $C$. dist $=C$. distans, B.deli $=$ B. delicatulum, C.conss $=$ C.constrictus, B.vari $=$ B. varians, C.laude $=$ C.lauderii and C.soci $=$ C. socialis . 
Table 2. Cells density (cells $\mathrm{L}^{-1}$ ), species richness (number of species), diversity (Shannon Weiner Index) and evenness (E) of total phytoplankton and order Chaetocerotales at Carey Island across the sampling months

\begin{tabular}{|c|c|c|c|c|c|c|c|c|c|c|c|c|}
\hline Sampling month & $\begin{array}{c}\text { Apr } \\
09\end{array}$ & $\begin{array}{c}\text { May } \\
09\end{array}$ & $\begin{array}{c}\text { Jun } \\
09\end{array}$ & $\begin{array}{c}\text { Jul } \\
09 \\
\end{array}$ & $\begin{array}{c}\text { Aug } \\
09\end{array}$ & $\begin{array}{c}\text { Sep } \\
09 \\
\end{array}$ & $\begin{array}{c}\text { Oct } \\
09\end{array}$ & $\begin{array}{c}\text { Nov } \\
09 \\
\end{array}$ & $\begin{array}{c}\text { Dec } \\
09 \\
\end{array}$ & $\begin{array}{c}\text { Jan } \\
10 \\
\end{array}$ & $\begin{array}{c}\text { Feb } \\
10 \\
\end{array}$ & $\begin{array}{c}\text { Mar } \\
\mathbf{1 0} \\
\end{array}$ \\
\hline \multicolumn{13}{|l|}{ Total phytoplankton } \\
\hline Cells density x $10^{3}\left(\right.$ cells L $\left.{ }^{-1}\right)$ & 3630 & 3540 & 579 & 4033 & 1969 & 912 & 627 & 929 & 515 & 1065 & 869 & 1257 \\
\hline No. of species & 34 & 38 & 50 & 7 & 27 & 24 & 24 & 26 & 21 & 24 & 24 & 23 \\
\hline Shannon Weiner Index $\left(\log _{2}\right)$ & 1.607 & 1.315 & 3.924 & 1.716 & 1.059 & 1.373 & 2.52 & 1.707 & 2.448 & 2.448 & 2.218 & 2.503 \\
\hline Evenness $(E)$ & 0.316 & 0.251 & 0.695 & 0.611 & 0.223 & 0.299 & 0.55 & 0.363 & 0.557 & 0.534 & 0.484 & 0.553 \\
\hline \multicolumn{13}{|l|}{ Order Chaetocerotales } \\
\hline Cells density x $10^{3}\left(\right.$ cells L $\left.{ }^{-1}\right)$ & 360 & 320 & 0 & 0 & 66 & 0 & 0 & 0 & 0 & 267 & 191 & 291 \\
\hline No. of species & 11 & 14 & 0 & 0 & 5 & 0 & 0 & 0 & 0 & 8 & 7 & 11 \\
\hline Shannon Weiner Index $\left(\log _{2}\right)$ & 3.195 & 2.86 & 0 & 0 & 2.114 & 0 & 0 & 0 & 0 & 2.359 & 1.893 & 3.236 \\
\hline Evenness $(E)$ & 0.924 & 0.751 & 0 & 0 & 0.91 & 0 & 0 & 0 & 0 & 0.786 & 0.674 & 0.936 \\
\hline
\end{tabular}

\section{Potential relationship between Chaetocerotales and physical and chemical parameters}

A Principal Component Analysis (PCA) was performed on the $\log (\mathrm{n}+1)$ of order Chaetocerotales cells abundance and the measured physical and chemical parameters. Initially, four and six chemical and physical parameters, respectively, were chosen by the PCA. However, only two chemicals (nitrate and phosphate) and four physical parameters (DO, temperature, $\mathrm{pH}$ and TDS) were retained in the PCA together with the Chaetocerotales species.

The dimension 1 (Dim. 1) and 2 (Dim. 2) of the PCA explained a total of $61.1 \%$ of the total variation. The Dim. 1 which explained $41.3 \%$ of the total variation (Figure $3 \mathrm{~A}$ ) displayed the relationship between the seventeen Chaetocerotales species with nitrate, phosphate, temperature and DO. Variable factor map of the PCA showed that ten of the Chaetocerotales species and nitrate concentration in the water column were strongly and positively correlated with the positive axis of the Dim. 1 . Species of C. socialis, C. lauderii, C.sp1, C.constrictus, B. delicatulum, C.distans, C. curvisetus, C.laciniosum. B. comosum, B. varians, and C.sp2 were the species together with nitrate that displayed significantly positive correlation with the Dim. $1(\mathrm{r}>0.7)$ of the PCA. The mentioned species occurred in relatively high abundance in the three sampling months that recorded with high nitrate concentration (> $0.5 \mathrm{mg} \mathrm{L}^{-1}$ ) (April 09; $1.2 \pm 0.1 \mathrm{mg} \mathrm{L}^{-1}$; May 09; $1.0 \pm 0.1 \mathrm{mg} \mathrm{L}^{-1}$; and; Mar 2010; $0.7 \pm 0.1 \mathrm{mg} \mathrm{L}^{-1}$ ) (Figure 3A and 3B). This further supported that nitrate concentration potentially significantly and strongly enhanced some Chaetocerotales species in the water column of the study site.

Nitrate in the water column was found to have strong effect on the Chaetocerotales species with major cells density, which were the $B$. comosum and $C$. curvisetus, and a few other species. The significant relationship between the Chaetocerotales in Carey Island could be attributed to their adaptation to living in the extreme mangrove ecosystem. Other than nutrients from anthropogenic runoff, mangrove also exposes to nutrient enrichment from detrital-sourced nitrogen (Roy et al. 2012), which possibly enhanced the nitrate concentration in this ecosystem. The positive relationship between nitrate and Chaetocerotales was possibly one of exclusive ecology of Chaetocerotales inhabiting the mangrove. This phytoplankton group ability to opportunistically use up the nitrate in this extreme condition may be the answer to their high cells abundance in high nitrate concentration in the months of April 2009, May 2009, and March 2010.

Phosphate concentration and the temperature of the water column were the other parameters that were retained in the PCA. The parameters and six species of Chaetocerotales namely the $C$. decipiens, $C$. delicatulum, C. tenuissimus, C. debilis, C. lorenzianus, and C. neglectus showed a positive correlation with the Dim. 1 at $\mathrm{r}<0.7$. Nitrate, phosphate and temperature were potentially the important parameters that positively stimulating the growth of order Chaetocerotales at the study site.

Positive relationship between the genus Chaetoceros and Bacteriastrum with phosphate concentration in the water column in this present study, has also been reported in numerous phytoplankton studies (Bosak et al. 2016; Yamaguchi et al. 2005a, b). This order of phytoplankton has proven to utilize a wide range of phosphate sources. They can take up and utilize the common source of organic phosphate and source of phosphate from inorganic phosphate and monophosphate monoester compound (Yamaguchi et al. 2005a) and from phosphate diester (Yamaguchi et al. 2005b). This ability may enable Chaetocerotales to outstand other phytoplankton species in response to repletion or depletion of this source of nutrient. The affinity of order Chaetocerotales towards wide range of phosphate possibly further explained their high cells abundance or bloom event in aquaculture, coastline and mangrove ecosystem. 

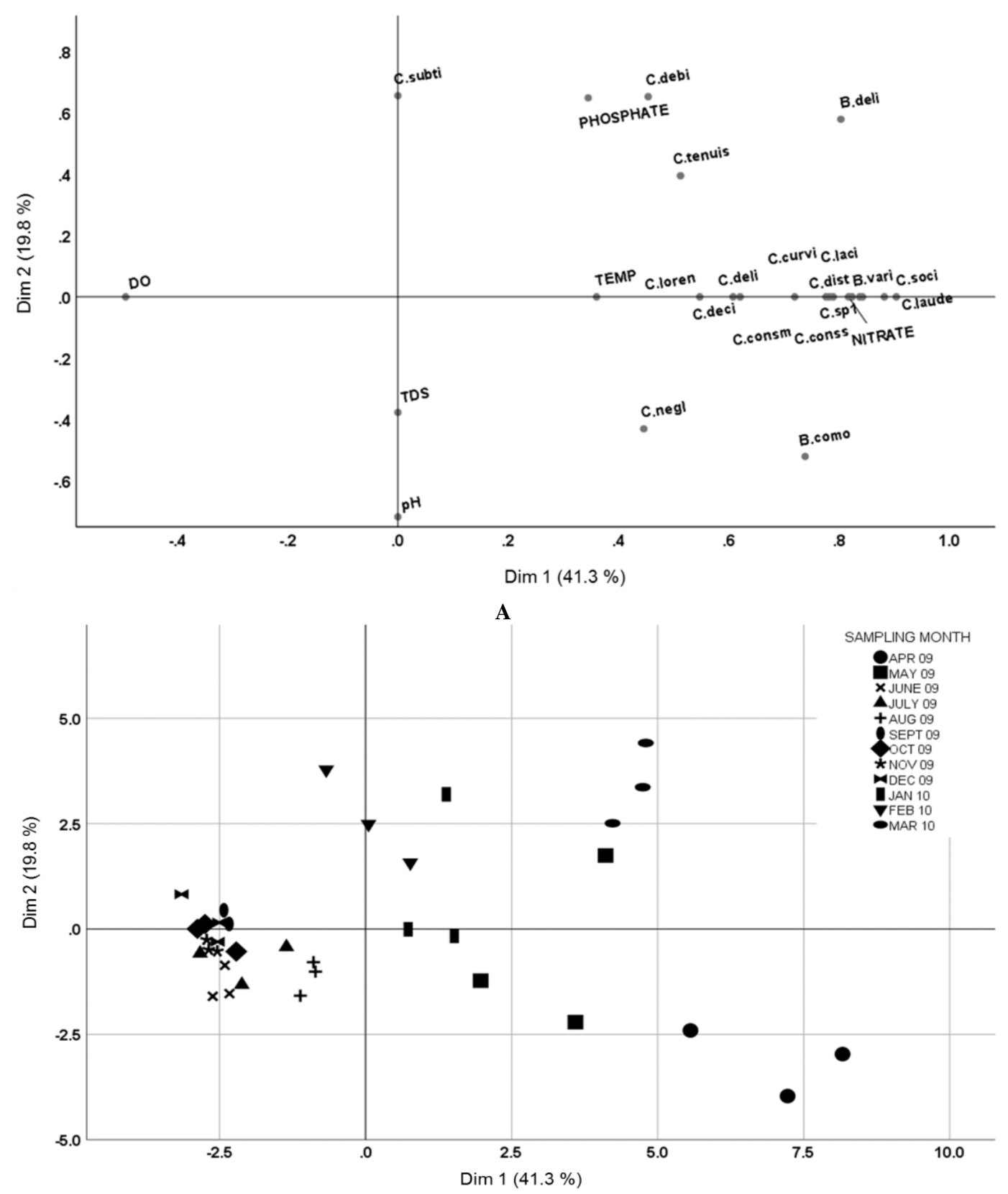

B

Figure 3. The output of Principal Component Analysis (PCA) displaying the relationship between Chaetocerotales and the physical and chemical parameters. A. Variables factor map and; B. Individual factor map of the PCA that was performed on the Chaetocerotales species composition and physical and chemical data (Table S1)

The low DO in the water column was possibly closely related to high Chaetocerotales cells density at the study site. Hypothetically, although high Chaetocerotales biomass due to their high density may lead to high DO due to high photosynthesis rate (Begum et al. 2015; Huo and Shu 2005), it could also cause hypoxia condition (Smayda 2006). Towards the end of high density or Chaetocerotales bloom event, most of the cells will be consumed by zooplankton or naturally dead (National Science and Technology Council 2016). Fecal matter from zooplankton and dead cells will be decomposed by bacteria which demands oxygen higher than oxygen being produced by the
Chaetocerotales species. Huo and Shu (2005) also reported low DO in the water column when period of high species density (bloom) Skeletonema costatum ended in Jiazhou bay, China. The next hypothesis is simply because the species in the Chaetocerotales opportunistically utilized the low DO concentration per L of water at the study site. Finding by Ochieng and Mary (2013) further supported this hypothesis by stating that it is the oxygen depletion towards the end of phytoplankton bloom that causes fish kills along the Kenyan Coasts. Also, DO level in the water column was higher in the months in which order Chaetocerotales was absent or in low density. 
In contrast to Dim. 1, only six species of order Chaetocerotales were significantly correlated with Dim. 2. The Dim. 2 however, only explained $19.8 \%$ of the total variation and displayed the relationship between some species of Chaetocerotales with TDS and $\mathrm{pH}$. Species $B$. delicatulum, $C$. tenussimus, $C$. debilis and $C$. subtilis were the species that positively correlated with the Dim. 2 of the PCA. Negative correlation between TDS and $\mathrm{pH}$ with the Dim. 2 potentially supported the negative relationship between the mentioned species with these parameters. The presence of $B$. comosum and $C$. neglectus were only recorded in the month of Apr and May 2009. Both months were characterized by comparably high TDS concentration and $\mathrm{pH}$ in the water column (Figure 3B). Four parameters, i.e., the silicate, sulfate, $\mathrm{CND}$, and salinity level in the water column did not have any significant correlation with both Dim. 1 and Dim. 2 of the PCA.

The species of order Chaetocerotales did not show any significant relationship with silicate concentration in the water column of Carey Island. Silicate concentration that showed a non-significant temporal variability throughout the sampling period could be the reason for this finding. The non-significant temporal variability displayed by silicate suggested that this nutrient potentially was likely available at sufficient concentration throughout the sampling period. Therefore, was not the limiting factor for Chaetocerotales growth at the study site.

The absence of order Chaetocerotales in few of the sampling months was hypothesized to closely relate to grazing activity by shrimp larvae. Through observation, there was high density of the larvae in the sampling months in which Chaetocerotales were not recorded. However, no investigation was done for further information.

In conclusion, with regards to their high cells abundance that relatively and negatively correlated with the total phytoplankton diversity, it could be concluded that Chaetocerotales is one group of phytoplankton that has significant ecological impact on mangrove ecosystem. Their positive response towards increased nitrate and phosphate is another matter that needs further attention. Therefore, it is perhaps worth including other forms of nitrogen and phosphate in future studies. In addition, their high density occurrence that negatively correlated with DO level also potentially able to cause hypoxia condition in the water column may lead to ecosystem instability. More works are needed, and more hypotheses need to be tested to fully understand the ecology of order Chaetocerotales inhabiting mangrove ecosystems.

\section{ACKNOWLEDGEMENTS}

This present study was carried out as part of the first author's (N.S. Redzuan) project, which was funded by SLAB-MOHE and University Malaysia Terengganu (UMT). The scientific study of this project was funded by University of Malaya' postgraduate grant (PPP) (PS2892010B).

\section{REFERENCES}

Begum M, Sahu BK, Das AK, Vinithkumar NV, Kirubagaran R. 2015. Extensive Chaetoceros curvisetus bloom in relation to water quality in Port Blair Bay, Andaman Islands. Environ Monit Assess 187: 1-14. DOI: $10.1007 / \mathrm{s} 10661-015-4461-2$.

Bellinger EG, Sigee DC. 2010. Algae as Bioindicators. In: Freshwater Algae. John Wiley \& Sons, New York. DOI: 10.1002/9780470689554.ch3

Bhattacharjee D, Samanta B, Danda AA, Bhadury P. 2013. Temporal succession of phytoplankton assemblages in a Tidal Creek System of the Sundarbans Mangroves: An integrated approach. Intl J Biodivers 2013: 1-15. DOI: 10.1155/2013/824543.

Booth BC, Larouche P, Bélanger S, Klein B, Amiel D, Mei ZP. 2002. Dynamics of Chaetoceros socialis blooms in the North Water. Deep Res Part II Top Stud Oceanogr 49: 5003-5025. DOI: 10.1016/S09670645(02)00175-3

Bosak S, Godrijan J, Šilović T. 2016. Dynamics of the marine planktonic diatom family Chaetocerotaceae in a Mediterranean coastal zone. Estuar Coast Shelf Sci 180: 69-81. DOI: 10.1016/j.ecss.2016.06.026.

Bosch-Belmar M, Milisenda G, Girons A, Taurisano V, Accoroni S, Totti C, Piraino S, Fuentes V. 2017. Consequences of stinging plankton blooms on finfish mariculture in the Mediterranean Sea. Front Mar Sci 4: 1-11. DOI: 10.3389/fmars.2017.00240.

Bruno DW, Dear G, Seaton DD. 1989. Mortality associated with phytoplankton blooms among farmed Atlantic salmon, Salmo salar L, in Scotland. Aquaculture 78: 217-222. DOI: 10.1016/00448486(89)90099-9.

Chang Lim H, Teng ST, Leaw CP, Iwataki M, Lim T. 2014. Phytoplankton assemblage of the Merambong Shoal, Tebrau Straits with note on potentially harmful species. Malayan Nat J 66: 198-211.

Evans JH. 1972. A modified sedimentation system for counting algae with an inverted microscope. Hydrobiologia 40: 247-250. DOI: 10.1007/BF00016796.

Facca C, Sfriso A. 2007. Epipelic diatom spatial and temporal distribution and relationship with the main environmental parameters in coastal waters. Estuar Coast Shelf Sci 75: 35-49. DOI: 10.1016/j.ecss.2007.03.033.

Gwak IG, Jung W, Kim HJ, Kang SH, Jin ES. 2010. Antifreeze protein in Antarctic Marine Diatom, Chaetoceros neogracile. Mar Biotechnol 12: 630-639. DOI: 10.1007/s10126-009-9250-x.

Hashimoto T, Hyodoh K, Hirose T, Nishikawa S, Katano T, Nakano SI. 2008. Evaluation of three phytoplankton species as food for the pearl oyster Pinctada fucata. Aquac Int 16: 309-318. DOI: 10.1007/s10499-007-9144-8.

Hasle G.R, Syvertsen E.E, 1997. Chapter 2 - Marine Diatoms, in: Tomas, C.R. (Ed.), Identifying Marine Phytoplankton. Academic Press, San Diego, CA. DOI: DOI: 10.1016/B978-012693018-4/50004-5.

Huo WY, Shu J-J. 2005. Outbreak of Skeletonema costatum Bloom and Its Relations to Environmental Factors in Jiaozhou Bay, China. 2005 WSEAS Int Conf Environ Ecosyst Dev 2005: 205-210.

Ishikawa A, Furuya K. 2004. The role of diatom resting stages in the onset of the spring bloom in the East China Sea. Mar Biol 145: 633-639. DOI: $10.1007 / \mathrm{s} 00227-004-1331-9$.

Kang K-H, Seon S-C, Kim J-Mi, Zhuo L-L, Lim S-M. 2009. Effects of three microalgae, Tetraselmis chuii, Chaetoceros calcitrans, and Phaeodactylum tricornutm on larvae and spat growth of the trumpet shell. Korean J. Malacol 25 (1): 35-40.

Manna S, Chaudhuri K, Bhattacharyya S, Bhattacharyya M. 2010. Dynamics of Sundarban estuarine ecosystem: Eutrophication induced threat to mangroves. Saline Syst 6: 1-16. DOI: 10.1186/1746-1448-68 .

Moore SK, Trainer VL, Mantua NJ, Parker MS, Laws EA, Backer LC, Fleming LE. 2008. Impacts of climate variability and future climate change on harmful algal blooms and human health. Environ Heal A Glob Access Sci Source 7: 1-12. DOI: 10.1186/1476-069X-7-S2-S4.

Ochieng E, Mary M. 2013. Potentially Harmful Algae along the Kenyan Coast: A Norm or Threat. J Environ Earth Sci 3 (9): 1-12.

Paterson RF, McNeill S, Mitchell E, Adams T, Swan SC, Clarke D, Miller PI, Bresnan E, Davidson K. 2017. Environmental control of harmful dinoflagellates and diatoms in a fjordic system. Harmful Algae 69: 117. DOI: 10.1016/j.hal.2017.09.002.

Poulsen LK, Reuss N. 2002. The plankton community on Sukkertop and Fylla Banks off West Greenland during a spring bloom and post- 
bloom period: Hydrography, phytoplankton and protozooplankton. Ophelia 56: 69-85. DOI: 10.1080/00785236.2002.10409491.

Razali RM, Leaw CP, Lim HC, Nyanti L, Ishak I, Lim PT. 2015. Harmful microalgae assemblage in the aquaculture area of Aman Island, Northen Strait of Malacca. Malaysian J Sci 34: 20-32.

Redzuan NS, Milow P. 2019. Skeletonema costatum of mangrove ecosystem: Its dynamics across physico-chemical parameters variability. AACL Bioflux 12: 179-190.

Roy M, Ray S, Ghosh BP. 2012. Modelling of impact of detritus on detritivorous food chain of Sundarban Mangrove Ecosystem, India Procedia Environ Sci 13: 377-390. DOI: 10.1016/j.proenv.2012.01.035.

Sidik MJ, Rashed-Un-Nabi M, Azharul Hoque M. 2008. Distribution of phytoplankton community in relation to environmental parameters in cage culture area of Sepanggar Bay, Sabah, Malaysia. Estuar Coast Shelf Sci 80: 251-260. DOI: 10.1016/j.ecss.2008.08.004
Smayda TJ. 2006. Harmful Algal Bloom Communities in Scottish Coastal Waters: Relationship to Fish Farming and Regional Comparisons - A Review February 2006 Paper 2006/3. Scottish Executive Environment Group, Scotland.

Yamaguchi H, Sakou H, Fukami K, Adachi M, Yamaguchi M, Nishijima T. 2005a. Utilization of organic phosphorus and production of alkaline phosphatase by the marine phytoplankton, Heterocapsa circularisquama, Fibrocapsa japonica and Chaetoceros ceratosporum. Plankt Biol Ecol 52: 67-75.

Yamaguchi H, Yamaguchi M, Fukami K, Adachi M, Nishijima T. 2005b. Utilization of phosphate diester by the marine diatom Chaetoceros ceratosporus. J Plankton Res 27: 603-606. DOI: 10.1093/plankt/fbi027. 
Table S1. Monthly variability of physical and chemical parameters at the study site

\begin{tabular}{|c|c|c|c|c|c|c|c|c|c|c|c|c|c|}
\hline Parameter & & Apr 09 & May 09 & Jun 09 & Jul 09 & Aug 09 & Sep 09 & Oct 09 & Nov 09 & Dec 09 & Jan 10 & Feb 10 & Mar 10 \\
\hline Nitrate & $\mathrm{N}$ & 3 & 3 & 3 & 3 & 3 & 3 & 3 & 3 & 3 & 3 & 3 & 3 \\
\hline \multirow[t]{2}{*}{$\left(\mathrm{mg} \mathrm{L}^{-1}\right)$} & Mean & 1.17 & 0.99 & 0.15 & 0.45 & 0.72 & 0.21 & 0.36 & 0.21 & 0.32 & 0.4 & 0.27 & 0.73 \\
\hline & Std. Error & 0.07 & 0.06 & 0.09 & 0.09 & 0.12 & 0.08 & 0.12 & 0.05 & 0.09 & 0.05 & 0.07 & 0.06 \\
\hline Phosphate & $\mathrm{N}$ & 3 & 3 & 3 & 3 & 3 & 3 & 3 & 3 & 3 & 3 & 3 & 3 \\
\hline \multirow[t]{2}{*}{$\left(\mathrm{mg} \mathrm{L}^{-1}\right)$} & Mean & 0.83 & 0.79 & 0.47 & 0.82 & 0.79 & 1.5 & 0.48 & 0.49 & 0.66 & 0.98 & 1.52 & 1.97 \\
\hline & Std. Error & 0.13 & 0.30 & 0.09 & 0.44 & 0.28 & 0.44 & 0.11 & 0.05 & 0.18 & 0.11 & 0.26 & 0.28 \\
\hline Silicate & $\mathrm{N}$ & 3 & 3 & 3 & 3 & 3 & 3 & 3 & 3 & 3 & 3 & 3 & 3 \\
\hline \multirow[t]{2}{*}{$\left(\mathrm{mg} \mathrm{L}^{-1}\right)$} & Mean & 2.89 & 3.22 & 1.49 & 4.32 & 3.5 & 2.04 & 2.52 & 1.98 & 0.93 & 2.66 & 2.16 & 2.62 \\
\hline & Std. Error & 0.55 & 0.41 & 0.23 & 2.28 & 0.93 & 0.52 & 0.80 & 0.36 & 0.22 & 0.53 & 0.40 & 0.39 \\
\hline Sulfate & $\mathrm{N}$ & 3 & 3 & 3 & 3 & 3 & 3 & 3 & 3 & 3 & 3 & 3 & 3 \\
\hline \multirow[t]{2}{*}{$\left(\mathrm{mg} \mathrm{L}^{-1}\right)$} & Mean & 54.5 & 89.83 & 69.5 & 55.17 & 43.5 & 50.33 & 57.67 & 66.67 & 52.5 & 35.17 & 52.33 & 38.17 \\
\hline & Std. Error & 1.61 & 15.80 & 10.69 & 9.43 & 8.55 & 12.60 & 19.16 & 12.20 & 3.28 & 8.74 & 3.09 & 2.77 \\
\hline \multirow{3}{*}{ Temperature $\left({ }^{\circ} \mathrm{C}\right)$} & $\mathrm{N}$ & 3 & 3 & 3 & 3 & 3 & 3 & 3 & 3 & 3 & 3 & 3 & 3 \\
\hline & Mean & 31.17 & 31.16 & 31.44 & 30.9 & 31.51 & 30.17 & 30.13 & 28.87 & 28.25 & 29.44 & 29.08 & 30.94 \\
\hline & Std. Error & 0.44 & 0.11 & 0.15 & 0.80 & 0.18 & 0.38 & 0.61 & 0.57 & 0.21 & 0.51 & 0.39 & 0.49 \\
\hline \multirow[t]{3}{*}{ CND } & $\mathrm{N}$ & 3 & 3 & 3 & 3 & 3 & 3 & 3 & 3 & 3 & 3 & 3 & 3 \\
\hline & Mean & 41457.7 & 44528.3 & 44788 & 43318.3 & 43510.7 & 37929.3 & 37964.3 & 37586.3 & 43257.7 & 45754.7 & 42650.3 & 44023 \\
\hline & Std. Error & 438.89 & 79.95 & 195.64 & 1131.17 & 526.27 & 3307.35 & 2028.74 & 1104.91 & 534.50 & 840.88 & 318.63 & 304.26 \\
\hline TDS & $\mathrm{N}$ & 3 & 3 & 3 & 3 & 3 & 3 & 3 & 3 & 3 & 3 & 3 & 3 \\
\hline \multirow[t]{2}{*}{$\left(\mathrm{mg} \mathrm{L}^{-1}\right)$} & Mean & 26.57 & 27.4 & 29.17 & 25.96 & 25.38 & 25.94 & 24.6 & 24.05 & 26.48 & 27.78 & 24.92 & 24.19 \\
\hline & Std. Error & 0.31 & 0.04 & 0.12 & 0.77 & 0.28 & 0.02 & 0.21 & 0.13 & 0.09 & 0.33 & 0.79 & 0.41 \\
\hline \multirow{3}{*}{ Salinity } & $\mathrm{N}$ & 3 & 3 & 3 & 3 & 3 & 3 & 3 & 3 & 3 & 3 & 3 & 3 \\
\hline & Mean & 25.85 & 28.62 & 28.77 & 25.29 & 24.63 & 20.6 & 21.33 & 22.66 & 25.97 & 25.24 & 24.52 & 24.6 \\
\hline & Std. Error & 0.51 & 0.06 & 0.14 & 0.75 & 0.26 & 0.25 & 1.24 & 0.60 & 0.10 & 1.87 & 1.09 & 0.85 \\
\hline \multirow[t]{3}{*}{$\mathrm{DO}\left(\mathrm{mg} \mathrm{L}^{-1}\right)$} & $\mathrm{N}$ & 3 & 3 & 3 & 3 & 3 & 3 & 3 & 3 & 3 & 3 & 3 & 3 \\
\hline & Mean & 1.84 & 2.11 & 5.37 & 3.53 & 2.55 & 3.96 & 4.04 & 2.75 & 4.26 & 3.76 & 3.43 & 2.42 \\
\hline & Std. Error & 0.40 & 0.44 & 1.51 & 1.48 & 0.35 & 0.91 & 0.87 & 0.44 & 1.52 & 0.81 & 0.16 & 0.43 \\
\hline \multirow[t]{3}{*}{$\mathrm{pH}$} & $\mathrm{N}$ & 3 & 3 & 3 & 3 & 3 & 3 & 3 & 3 & 3 & 3 & 3 & 3 \\
\hline & Mean & 7.92 & 7.86 & 7.64 & 7.47 & 7.86 & 7.46 & 7.2 & 7.82 & 6.9 & 7.27 & 6.92 & 6.89 \\
\hline & Std. Error & 0.07 & 0.02 & 0.19 & 0.20 & 0.01 & 0.16 & 0.17 & 0.02 & 0.15 & 0.31 & 0.07 & 0.08 \\
\hline
\end{tabular}

